\title{
Dětské čtenářství v didaktických souvislostech a perspektivy neurovědních poznatků ${ }^{1}$
}

\author{
Václav Jindráček ${ }^{a}$, Jiří Škoda ${ }^{b}$, Pavel Doulík ${ }^{b}$ \\ ${ }^{a}$ Univerzita Jana Evangelisty Purkyně v Ústí nad Labem, Pedagogická fakulta, \\ Katedra bohemistiky

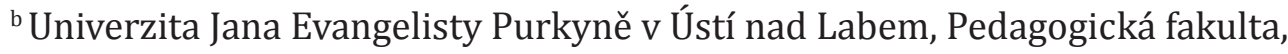 \\ Katedra pedagogiky
}

Redakci zasláno 3. 12. 2012 / upravená verze obdržena 31. 5. 2013 / k uveřejnění přijato 24. 6. 2013

\begin{abstract}
Abstrakt: Cílem této přehledové studie je vyhledat výzkumné práce, které funkčními či elektrofyziologickými metodami vyšetřovaly aktivaci korových oblastí mozku v průběhu čtení vyprávění (tj. narativu či diskurzu), a s pomocí přehledových studií podat systematický souhrn výsledků, k nimž vybrané výzkumy dospěly. První část příspěvku je věnována současnému dětskému čtenářství $v$ didaktických souvislostech a didaktické transformaci obsahu v literární výchově. $\mathrm{V}$ následující části je podán přehled výzkumných studií mapujících aktivaci korových oblastí mozku v průběhu čtení a porozumění narativu/diskurzu. Jako zdroj dat byly použity databáze (2007-2012): Medline, Bibliomedica, Science Direct, Web of Science, Google Scholar. Do analýzy bylo zařazeno 16 výzkumných studií. Ukázalo se, že dohledané práce jen ojediněle zohledňovaly specifika pubescentních a prepubescentních čtenářru, i přesto však podaly široký přehled možností, jimiž lze objasňovat mechanismy procesu čtení narativního textu na úrovni korové aktivace mozku. Velký význam byl v hodnocených článcích přisouzen zejména výzkumu činnosti mozkových oblastí/hemisfér v průběhu konstrukce tzv. situačních modelů (ev. během segmentace vyprávění do jednotlivých akcí/událostí) a vymezování kontrastů, které charakterizují neuronální koreláty inferenčních procesů.
\end{abstract}

Klíčová slova: neurovědy, dětské čtenářství, didaktická transformace obsahu

Mnohé empirické výzkumy dětského (prepubescentního a pubescentního) čtenářství, které byly v naší zemi realizovány po roce 1989 (Pourová, 1996; Toman, 1999; Lederbuchová, 2004; Gabal \& Václavíková-Helšusová, 2005; Vala, 2011 ad.), ukázaly, že nedospělý čtenář se ve srovnání se svým předlis-

1 Tato studie byla zpracována $\mathrm{v}$ rámci řešení studentského grantového projektu IGA UJEP Využití poznatků o prekoncepcích v literární výchově. 
topadovým vrstevníkem pronikavě změnil: mentálně akceleroval, technicky vyspěl a ve výběru zájmové četby i mediálního zážitku se prudce osamostatnil (Toman, 2004). V četbě beletrie a v audiovizuální recepci (zvláště v televizním diváctví a poslechu populární hudby) se však nevyhranil ani věkově, ani hodnotově, spíše tíhnul k vyšší věkové kategorii (Toman, 2009, s. 38). Tento trend ovlivnil nejen čtenářskou vyspělost a literární zájem dnešních dětí, ale velice silně i rozsah, frekvenci a kvalitu jejich četby. Vzbudil ovšem i nové otázky a teoretické úvahy nad výzvami či perspektivami didaktických přístupů k rozvoji dětského čtenářství. Jak ukazují zahraniční přehledové studie (Hruby \& Goswami, 2011; Marmolejo-Ramos et al., 2009), v současné době se v otázkách literární výchovy a dětského čtenářství máme možnost opírat i o poznatky z oblasti vědeckých disciplín, které přistupují k procesům lidského učení a k popisu čtenářské aktivity pomocí výzkumů orgánové, buněčné i molekulární úrovně mozkové činnosti - tzv. neurověd (viz také Jonák, 2007).

Cílem tohoto př́spěvku je (1) krátce nastínit základní aspekty současného dětského čtenářství v didaktických souvislostech; (2) seznámit se zvláštnostmi didaktické transformace obsahu v literární výchově; (3) představit výzvy a možnosti neurovědních poznatků v kontextu teoretických přístupů k dětskému čtenářství; (4) vyhledat výzkumné práce, které funkčními či elektrofyziologickými metodami vyšetřovaly aktivaci korových oblastí mozku v průběhu čtení příběhu/vyprávění (tj. narativu či diskurzu); (5) s pomocí vyhledaných přehledových studií podat systematický souhrn výsledků, k nimž vybrané výzkumy dospěly, a zhodnotit, jak uvedená zjištění přispívají k objasnění mechanismů procesu čtení s porozuměním narativnímu textu.

\section{Dětské čtenářství ve škole a literární výchova}

Řada výzkumů prepubescentního a pubescentního čtenářství, uskutečněná v uplynulých dvaceti letech, shodně zaznamenala, že čtenářská aktivita dětské populace trvale klesá (Toman, 2009, s. 35). ${ }^{2}$ Př́ičiny dětského nezájmu

Tyto poznatky potvrzuje a doplňuje i mezinárodní výzkum PISA, který se dlouhodobě zabývá čtenářskou gramotností patnáctiletých žáků (byt' ji zkoumá i na jiných druzích textů než uměleckých). Čtenářská gramotnost byla ve výzkumu PISA 2009 definována jako „schopnost porozumět psanému textu, zabývat se jím, přemýšlet o něm a používat ho k dosažení vlastních cílů, k rozvoji vlastních vědomostí a potenciálu a k aktivní účasti ve společnosti“ (Palečková, Tomášek, \& Basl, 2010, s. 12). Zjistilo se, že v České republice mezi lety 2000-2009 průměrný výsledek patnáctiletých žáků v čtenářské gramotnosti výrazně poklesl (ibid, s. 18). 
o četbu badatelé nejčastěji hledali v negativním vlivu pokleslé a zkomercializované knižní produkce, $v$ konkurenci informačních technologií dnešní doby a v nestimulativním rodinném prostředí (Toman, 2004). Jedna z nejvážnějších příčin nečtenářství však byla spatřována také $\mathrm{v}$ nízké efektivitě školní literární výchovy. ${ }^{3}$ Nepochybně i vzhledem k tomu, že rozvoj a podpora čtenářství není jedinou cílovou kategorií literární výchovy, ale má být účelně provázána s obecnými funkcemi umělecké literatury a s dalšími výchovněvzdělávacími oblastmi, jež se podílejí na optimálním rozvoji žákovy osobnosti (Kusá, 2012, s. 55).

Z hlediska vzdělávací struktury - s ohledem na specifické kvality slovesného umění - je školní literární výchova spjata s výchovou jazykovou a komunikační (slohovou). Podle kurikulárních dokumentů (RVP ZV, 2007) tak žáci postupně poznávají strukturu uměleckých děl a estetické tvořivé činnosti (autorské i vnímatelské), které (re)konstruují ve svých znalostech o literatuře a především $\mathrm{v}$ dovednostech kultivované čtenářské komunikace s literárními díly. ${ }^{4}$ Nabývají tím kompetence k odpovídajícím činnostem, tj. k orientaci $\mathrm{v}$ textové struktuře, $\mathrm{v}$ myšlenkové stavbě, $\mathrm{v}$ principech a postupech estetického uspořádání jazykového i tematického materiálu slovesného díla, k recepčně-interpretačním aktivitám a estetickým činnostem, o které se mohou a mají opírat základní poznatky a pojmy z teorie literatury (viz Lederbuchová, 2006). Poznatková báze školní literární výchovy je nezbytná stejně jako hodnotová složka učiva a dovednosti, které si žák v komunikaci $\mathrm{s}$ učitelem a v kontaktu s uměleckými texty vytvoří.

Didaktická transformace obsahu jako mediační proces, jímž žáci s pomocí učitele (re)konstruují obsah jako svou znalost a dovednost (Knecht, 2007; Janík, 2009, s. 656-660; Janík \& Slavík, 2009; Slavík, 2011, s. 210; Janko, 2012), je v literární výchově podmíněna uměleckou podstatou (a estetickou funkcí) literatury stejně jako čtenářskou kompetencí žáků. Četba beletrie (estetické

3 Prokázal to např́íklad výzkum, který byl uskutečněn v roce 2002 a v němž bylo dotazováno 1092 dětí ve věku 10-14 let. Z jeho výsledků vyplynulo, že více než čtvrtina respondentů byla ze strany školy v péči o čtenářství zanedbávána a škola neplnila v této oblasti vzdělávání ani jinak běžný standard (Gabal \& Václavíková-Helšusová, 2005).

4 S ohledem na školní praxi je nutné explicitně upozornit na rovinu metakognice. Tu je nutné vnímat jako základní složku čtenářské gramotnosti, nepostradatelnou pro kultivaci (nejen) pubescentního čtenářství ( $\mathrm{v}$ dovednosti reflektovat záměr vlastního čtení, v souladu s ním volit texty a způsob čtení, sledovat a vyhodnocovat vlastní porozumění čtenému textu a záměrně volit strategie pro lepší porozumění, pro překonávání obtížnosti obsahu i složitosti vyjádření, viz Koštálová et al., 2010, s. 14). 
poznání světa v dílech umělecké literatury) umožňuje objevovat rozmanité životní situace, prríběhy, konflikty, charaktery a osudy jiných lidí, umožňuje rekonstruovat fikční světy a prožívat to, co je ve skutečném životě nemožné nebo jen stěží představitelné. Dovednost kultivované komunikace s uměním, cíleně rozvíjená literární výchovou, tak usměrňuje žákův estetický zážitek a působí také na vlastní žákovu hodnotovou orientaci (podněcuje jeho čtenářský vkus, utváří kulturní návyk četby, ovlivňuje žákův životní styl, sebehodnocení i mravní postoje - viz Lederbuchová, 2006). Zaměřením na osobnost žáků a na rozvíjení jejich osobní identity v sociálních a kulturních kontextech má pak literární výchova mnoho společných cílů i s ostatními estetickými obory (s výtvarnou, hudební a dramatickou výchovou; Slavík, 2011, s. 207-208).

\section{Didaktické souvislosti a perspektivy}

Z didaktického hlediska bývá zdůrazňováno, že čtenářská recepce má silný psychosociální význam (v rozvoji lidské komunikace, sociálních vazeb, psychických procesů a schopnosti sebereflexe), je nezastupitelnou složkou v ontogenezi lidského jedince a v rozšiřování jeho emocionálněestetických zážitků, imaginace a představivosti (Toman, 2004). Reflektují to i metody, které umožňují rozvíjet klíčové čtenářské dovednosti žáků př́mo v pedagogické praxi. Značně př́nosné jsou v tomto ohledu principy artefiletiky a zážitkové pedagogiky, zvláště v kontextu tvořivé a diskurzivní interpretace uměleckého textu, během níž žák aktivně a svobodně vstupuje do komunikačního procesu četby $\mathrm{v}$ dialogu $\mathrm{s}$ učitelem i s ostatními žáky (např. Slavík, 2001). Literárněvýchovné uplatnění nalezly metody nabízené programem RWCT (čtením a psaním ke kritickému myšlení - Reading \& Writing for Critical Thinking), často vhodně kombinované se strategiemi vizualizace a propojování životní zkušenosti s přečteným (viz Šafránková, 2012). Neotřelé praktické podněty poskytují i široce uplatnitelné metody tvůrčího psaní, tvořivé dramatiky a kreativní interpretace (Hník, 2007) a v současnosti také postupy tzv. dílny čtení (Šlapal, 2010). Rozvojem individuální zkušenosti, zážitků a tvůrčí aktivity žáků ukazují efektivní cestu, jak systematicky pracovat $s$ emocionalitou dětských čtenářu a kultivovat ji v citlivost $\mathrm{k}$ estetickým zvláštnostem a mnohoznačnostem uměleckého výrazu. Výhody jejich pedagogického využití ukázala již školní praxe (viz Koštálová et al., 2010) a upozornily na ně i vědecké výzkumy (Vala, 2011). 
Badatelé zabývající se dětským čtenářstvím však mají možnost obrátit svou pozornost i $\mathrm{k}$ oborům, které $\mathrm{v}$ uplynulých letech přispěly $\mathrm{k}$ poznatkům o recepci literárního díla $\mathrm{v}$ rovině teoretické. Zvláštní perspektivu nabízí v tomto směru kognitivní věda, jejíž výsledky se v posledních desetiletích staly významnou inspirací zejména pro teorii vyprávění (Koten, 2012, s. 64). Př́́běh, který existuje jako abstrakce $\mathrm{v}$ mysli čtenáře, začal být inovativně popisován jako „produkt mentální obraznosti“ a „kognitivní konstrukt"; průzkumy přirozených vyprávění poskytly data, z nichž vyplývá, že události, o nichž čteme, vkládáme do situačních modelů či kognitivních rámců (Emmott, 1997); kognitivisticky orientovaní naratologové zavedli koncept textových a př́iběhových světů (Hermann, 2006) a značnou pozornost upoutala teorie schémat, podle které v četbě využíváme analogické zkušenosti a prototypické představy uchovávané v paměti (Emmott, 1997). Badatelský zájem se dotýká i kompetencí náležitého čtení narativního textu, a to včetně jeho emocionálního prožívání. Literární teorie se s touto problematikou vyrovnává mimo jiné prostřednictvím konceptu zanoření (Ryan, 2001) či v obecném promýšlení problematiky estetické iluze (Gerrig, 1998).

Současné zahraniční přehledové studie (např. Hruby \& Goswami, 2011) poukazují na skutečnost, že čtenářské a pedagogické výzkumy mohou čerpat informace i z dalších vědeckých disciplín, které dokážou k popisu čtení a porozumění narativu přistupovat exaktním způsobem. A to s pomocí argumentů vyplývajících z poznatků tzv. neurověd a z výzkumů orgánové, buněčné a molekulární úrovně mozkové činnosti. ${ }^{5} \mathrm{~S}$ ohledem na didaktické aspekty se tuto skutečnost pokusíme zhodnotit i v naší přehledové studii.

V následující kapitole poskytneme přehled výsledků vybraných výzkumných prací, které studovaly aktivitu korových oblastí mozku při čtení příběhu/vyprávění (tj. narativu či diskurzu), a pokusíme se je zhodnotit (srovnat) z hlediska jejich zaměření a využitých metod. Vyhodnocené údaje zkonfrontujeme s výsledky metaanalýzy popisující neuroanatomické koreláty kogni-

\footnotetext{
Ve snaze popsat a charakterizovat aktivitu a mechanismy mozkových funkcí v procesech učení a vyučování se už v devadesátých letech minulého století konstituovaly obory neuropedagogiky a neurodidaktiky (viz např. Friedrich, 2005; Herrmann, 2006; Preis, 1998 ad.). Za tímto účelem vzniklo v zahraničí již několik významných neurodidaktických center, která se zabývají aplikací a transferem neurovědních poznatků do oblasti didaktik. V r. 2005 vzniklo Centrum pro neurovědy ve vzdělávání na univerzitě v Cambridgi, v r. 2004 bylo založeno Centrum pro transfer neurověd do vzdělávání na německé univerzitě v Ulmu. Prestižní místo ve výzkumu kognitivního vývoje, vzdělávání a mozku zaujala i Harvardská univerzita programem Mind, Brain, and Education.
} 
tivních procesů a subprocesů při vytváření tzv. situačních modelů a mentálních reprezentací textu, diskurzivního kontextu a pragmatických interpretací (Ferstl et al., 2008). Vybrané souvislosti doplníme o poznatky přehledových studií orientovaných na problematiku funkční neuroanatomie porozumění textu (Ferstl, 2007) a vlivu předchozích znalostí čtenáře na porozumění narativu (Marmolejo-Ramos et al., 2009). S pomocí přehledové studie o významu neurověd pro čtenářské a pedagogické výzkumy (Hruby \& Goswami, 2011) se pokusíme posoudit, zda mohou uvedená zjištění přispět k objasnění mechanismů čtenářského zážitku, případně k vysvětlení způsobů, jimiž tento zážitek formuje čtenářskou zkušenost na základě subjektivní „obsahové transformace" z četby. Závěrem se pokusíme zkonfrontovat výsledky naší přehledové studie s názory, které vycházejí z předpokladu, že neurovědy budou pravděpodobně brzy ovlivňovat teoretické konstrukty o čtenářském vzdělávání, a tím mohou začít spolurozhodovat o cílech a směřování vzdělávací politiky.

\section{$3 \quad$ Přehled výzkumných studií mapujících aktivaci korových oblastí mozku v průběhu čtení a porozumění narativu/diskurzu ${ }^{6}$}

\subsection{Východiska a cíle}

Souvislosti mezi pedagogickým výzkumem, čtenářskými teoriemi a neurovědními poznatky ${ }^{7}$ se staly předmětem již několika systematických přehledových studií (např. Hruby \& Goswami, 2011). Jejich autoři dospěli k názoru, že možnosti čtenářského a literárního vzdělávání vytvářejí ideální prostor k návrhu inovativních kurikulárních modelů, podložených informacemi z výzkumů neuronálních korelátů psychických procesů, které lze zachytit a popsat v průběhu čtení a porozumění textu. Ukázalo se totiž, že poznatky o aktivaci korových oblastí mozku mohou významně přispět k objasnění důležitých otázek, v jejichž rámci jsou tvořeny a formulovány koncepty optimálních vzdělávacích strategií (ibid, s. 168).

\footnotetext{
Hruby a Goswamiová (2011, s. 166) uvádějí, že diskurz představuje v neurolingvistickém výzkumu obvykle narativní text se všemi jeho mikro- a makrostrukturálními prvky. Jak konstatuje Jedličková (2010, s. 93), „základními komponentami narativní struktury jsou prostor, čas, postava a děj; nejmenší narativní jednotkou je pak epická situace [...], která je konkretizací obecných komponent uvedených do vzájemného vztahu“.

7 Jako neurovědy se zpravidla označují disciplíny v rozsahu od neuroanatomie a neurofyziologie přes neuropsychologii a neurofilozofii k výpočetní neurovědě.
} 
Ve shodě s uvedenými poznatky se lze domnívat, že v teoretické i aplikační rovině věd o výchově a dětském čtenářství mohou sehrát důležitou roli zejména studie (výzkumné práce, systematické přehledy i metaanalýzy), které shromažd'ují informace o mozkových oblastech aktivovaných čtenářskými úlohami zaměřenými na dekódování slov, jednoduchých vět a souvětných konstrukcí. Funkci čtenářských mechanismů pak mohou objasnit i výzkumy mapující mozkovou aktivitu v průběhu čtenářského zpracovávání syntaktických a sémantických struktur textových pasáží a při vytváření tzv. situačních modelů a mentálních reprezentací narativních textů. ${ }^{8} \mathrm{Jak}$ naznačila $\mathrm{v}$ přehledové studii Ferstlová (2007), klíčovou roli mají v tomto směru především výzkumy prováděné pomocí tzv. hemodynamických a elektrofyziologických zobrazovacích metod (především fMRI, PET, EEG a MEG). ${ }^{9}$

V závislosti na technických parametrech zobrazovacích metod lze s různou přesností identifikovat změny v aktivitě jednotlivých korových oblastí mozku. Hemodynamické metody, založené na měření průtoku krve v mozkových oblastech (regional cerebral blood flow - $r C B F$ ), umožňují vizualizovat, lokalizovat a poměrně dobře rozlišit (s přesností až $3 \mathrm{~mm}^{3}$, viz Houdek, 2008, s. 2) nárůst průtoku okysličené krve spjatý s nárůstem aktivity zcela konkrétních mozkových struktur. Lze tak stanovit významné korelace mezi aktivací určitých mozkových oblastí a řešením specifického (jazykového) úkolu. Funkční magnetická rezonance (fMRI) detekuje poměr oxya deoxyhemoglobinu v krvi (tzv. BOLD efekt - blood oxygen level dependence) a změny úrovně průtoku okysličené krve pomocí silného magnetického pole. Pozitronová emisní tomografie (PET) umožňuje snímat změny metabolismu nebo krevního toku podle toho, nakolik jsou vyšetřované tkáně schopny vstřebat podanou radioaktivní látku, tj. radiofarmakum (nejčastěji modifikovanou molekulu glukózy). ${ }^{10}$

8 Podrobný výklad mentálních reprezentací přinesla Sedláková (2004). Jako mentální reprezentace se nejčastěji označují vnitřní subjektivní „obrazy“ vnější skutečnosti v mysli člověka. Formou mentální reprezentace je mentální model, tj. vnitřní reprezentace informace, která koresponduje s tím, co je reprezentováno (ibid, s. 58). Viz také Janko (2012, s. 26).

9 K parametrům elektrofyziologických a hemodynamických metod v neurolingvistice viz Schmiedtová a Flanderková (2012, s. 54).

10 Není v možnostech této studie podat úplný přehled základních zobrazovacích metod. Odkazujeme proto na př́slušnou odbornou literaturu (např. Kulišták, 2011; Preiss et al., 2006). Informace o metodách, jako jsou např. jednofotonová emisní počítačová tomografie (SPECT), transkraniální magnetická stimulace (TMS) nebo ultrazvukové transkraniální dopplerovské vyšetření (TCD), lze čerpat i z dostupných odborných článků (viz Hluštík et al., 2008; Tuček, 2002, tam i další literatura). 
Metody označované jako elektrofyziologické sledují elektrické impulzy, které vznikají současným působením neuronů kůry i podkorových struktur. Projevy bioelektrické aktivity jsou zpravidla snímány z povrchu hlavy pomocí většího počtu elektrod (obvykle 16-64 kanálů; viz Kulišták, 2011, s. 52) a vypovídají o činnosti dílčích neuronových obvodů v různých jednotkách času. Bioelektrické potenciály zachycuje elektroencefalografie (EEG), změny v jejich magnetických polích dokáže zaznamenat magnetoencefalografie (MEG). Technické principy všech zmiňovaných zobrazovacích metod jsou však značně komplikované a mají svá omezení daná zejména časovou a prostorovou rozlišovací schopností. Koukolík (2012, s. 26) a Chlebus et al. (2005, s. 133) upozorňují, že např. fMRI a PET rozlišují dobře prostorově, hůře v čase (jejich rozlišovací schopnost je kolem 1 sekundy), naproti tomu EEG a MEG rozlišují dobře v čase ( $\mathrm{v}$ milisekundách), ale špatně v prostoru. Oba druhy metod lze ovšem velmi dobře kombinovat, a tím se mohou překonat i jejich limity.

Je třeba si uvědomit, že z metodické povahy zobrazovacích technik nutně vyplývají jen vzájemné korelace sledovaných jevů a nelze hovořit o příčinných vztazích (viz Houdek, 2008, s. 11). Mezi konkrétní jazykovou úlohou a aktivitou určité korové oblasti mozku tak může existovat vztah, jenž sám o sobě zdaleka nemusí znamenat kauzální souvislost. Ani aktivita nebo útlum některé korové oblasti neznamená její př́mou účast nebo neúčast v projevech jazykové aktivity, nebot' určitá korová oblast může současně dostávat informace z jiné aktivní nebo neaktivní oblasti (Koukolík, 2012, s. 173). Sít' neuronů umožňující určitou jazykovou funkci je totiž založena na paralelním přenosu informací a její struktura se neustále mění jak do počtu napojených neuronů, tak do intenzity jejich vzájemného propojení (Houdek, 2008, s. 8).

Marmolejo-Ramos et al. (2009) v přehledové studii ukázali, že mozková aktivita během čtení a porozumění textu byla doposud ve výzkumných pracích sledována v několika rovinách: (1) při zatížení syntaktickými a sémantickými úlohami (např v průběhu identifikace gramatických vztahů mezi slovy ve větě a v souvětí a během dekódování frazémů a idiomů ve větách a v textových pasážích), (2) na úrovni textu (během percepčního zpracovávání explicitních textových propozic a prostředků vytvářejících koheznost, výrazovou spojitost textu) a (3) v rovině situační (zahrnující informace o lidech, prostředí, akcích a událostech explicitně vyjádřených nebo implicitně přítomných $\mathrm{v}$ textu). Neurověda tak v posledních deseti až patnácti letech poukázala i na zásadní význam zkoumání neuronálních korelátů inference (usuzování či vysuzování) a vybavování předchozích představ či souvislostí v průběhu 
vnímání a zpracování konotacía na konotaci založených nepř́mých obrazných pojmenování (metafor a metonymií; viz Hruby \& Goswami, 2011, s. 166). Tuto skutečnost potvrdila i Ferstlová (2007, s. 55) v přehledové studii o neuronálních korelátech porozumění narativnímu textu a poukážeme na ni také v následujícím přehledu vybraných výzkumných studií.

Cílem předložené přehledové studie je (1) vyhledat výzkumné práce, které funkčními či elektrofyziologickými metodami vyšetřovaly aktivaci korových oblastí mozku v průběhu čtení vyprávění (tj. narativu či diskurzu); (2) s pomocí vyhledaných přehledových studií podat systematický souhrn výsledků, k nimž vybrané výzkumy dospěly; (3) zhodnotit, jak uvedená zjištění přispívají k objasnění mechanismů procesu čtení s porozuměním narativnímu textu.

\subsection{Metodika}

V souladu se stanoveným cílem byla formulována výzkumná otázka: Jak přispívají k objasnění mechanismů čtenářského zážitku empirická zjištění, která vyplývají ze studií mapujících korovou aktivitu při čtení narativních textů?

Pro získání relevantních zdrojů dat (2007-2012) byly využity odborné licencované a volně př́stupné databáze: Medline, Bibliomedica, Science Direct, Web of Science, Google Scholar. K vyhledávání byla zvolena klíčová slova: („narrative comprehension“ or „reading stories“ or „narrative text" or „story perception“) and („neuroimaging“ or "neural correlates“ or „brain activity“ or „neural activity").

Do přehledu a následné analýzy byly zařazeny:

1. studie publikované $\mathrm{v}$ angličtině $\mathrm{v}$ recenzovaných vědeckých časopisech („peer-reviewed journals“) v období od ledna 2007 do prosince 2012;

2. studie, které funkčními či elektrofyziologickými zobrazovacími metodami (fMRI, PET, EEG, MEG aj.) experimentálně ověřovaly proměny aktivity lidského mozku v průběhu čtení narativního textu (obsahujícího minimálně dvě navazující věty) a v průběhu porozumění konotacím a nepřímým obrazným pojmenováním (např. metaforám);

3. výzkumy realizované na vzorku minimálně čtyř jedinců/praváků (mužů i žen) bez diagnostikovaných vývojových, neurologických nebo psychických poruch ve věku od 3,0 let. 
Vybrané studie musely splňovat všechna stanovená kritéria. U každého vybraného článku byly zaznamenávány následující proměnné: způsob výběru zkoumaného souboru, typ využitých zobrazovacích metod, metody analýzy obrazových dat (morfometrie celého mozku [whole-brain] / analýza oblasti zájmu - region of interest [ROI]), konkrétní stimulační podnět (typ vykonávané činnosti), pohlaví, průměrný věk, aktivované mozkové oblasti a hlavní nálezy (experimentální vs. kontrolní skupina).

Celkem bylo nalezeno 219 článků. Všechna stanovená kritéria splňovalo 16 experimentálních studií. Vyřazeny byly články, které hledaly neuroanatomické koreláty porozumění narativům při poslechu mluveného slova a při zatížení neslovními úlohami (např. sledování videa). Začleněny však byly studie, které tyto aktivity hodnotily ve srovnání s činností čtenářskou. Vyřazeny byly články sledující neuroanatomické koreláty čtení samostatných oddělených slov nebo jednotlivých vět, v ojedinělých případech i celých souvislých textů, ty byly ovšem vyřazeny pouze za předpokladu, že šlo o texty, které nebylo možné považovat za narativní (např. texty výkladové). Studie mapující korovou aktivitu v průběhu čtení samostatných vět byly do přehledu zařazeny pouze tehdy, pokud sledovaly mozkové oblasti aktivované čtenářskými úlohami zaměřenými na porozumění konotacím a nepřímým obrazným pojmenováním (metaforám).

\subsection{Výsledky}

Čtenářské mechanismy při recepci narativních textů byly $\mathrm{v}$ nalezených výzkumných studiích objasňovány pomocí experimentů, které využily hemodynamické či elektrofyziologické zobrazovací metody k tomu, aby vyhledaly neuroanatomické koreláty individuálních rozdílů v dovednosti čtení s porozuměním a identifikovaly, $v$ jakém rozsahu textové charakteristiky modulují korovou aktivaci během čtení narativu/diskurzu. $V$ následujícím přehledu postupně představíme výsledky studií, které (1) mapovaly aktivace mozkových oblastí/hemisfér v průběhu konstrukce tzv. situačních modelů a během segmentace vyprávění do jednotlivých akcí/událostí (5 studií) a které (2) hledaly neuronální koreláty inferenčních procesů při čtení narativních textů (5 studií). (3) Přehled uzavřeme souhrnem výsledků, k nimž dospěly výzkumy, které sledovaly některé specifické otázky korové aktivace v průběhu čtení a porozumění narativu ( 6 studií).

Aktivitu mozku v průběhu segmentace vyprávění do jednotlivých akcí (událostí) vyšetřovali Speer et al. (2007). Dobrovolníci četli jednoduchá vyprávě- 
ní o denní činnosti sedmiletého chlapce, aby je později při opětovném čtení rozdělili do větších a menších událostí (akcí). S využitím funkční magnetické rezonance (fMRI) výzkum podpořil teorii, že čtenáři segmentují příběh do oddělených událostí na základě změn ve vyprávěcí situaci a změn, které se vztahují k cílům postav vystupujících v příběhu. První kontakt s textem byl doprovázen přechodným zvýšením neuronální aktivity v momentech, kdy se čtenáři setkali s částmi př́iběhu, které později - během druhého čtení - sami označili za části „hraniční", tj. za hranice mezi dvěma událostmi. Vnímání těchto hranic bylo doprovázeno významně vyšší aktivitou mozkových oblastí, které podle předchozích výzkumů (Zacks et al., 2001) zvyšují svou činnost i v reakci na hranice mezi událostmi v průběhu sledování filmů (jedná se o sít' zahrnující velkou část posteriorního mediálního kortexu, anteriorní a superiorní temporální gyrus a gyrus subcallosus). Speer et al. (2007, s. 453) přitom ukázali, že aktivace uvedených oblastí je významně vyšší během čtení souvislých příběhů než při čtení vět, které spolu navzájem nesouvisejí. S pomocí výzkumu činnosti korových oblastí mozku tak autoři potvrdili platnost základního předpokladu porozumění narativnímu textu: aby čtenáři porozuměli situacím popisovaným v příběhu, vytvářejí si sérii jejich mentálních modelů - tzv. modelů situačních (tj. koherentních reprezentací postav, míst a aktivit popisovaných $v$ textu). Přehled čtyř studií, které mapovaly aktivaci mozkových oblastí v průběhu konstrukce situačních modelů a segmentace událostí čteného vyprávění, podává tabulka 1.

Činnost mozku při segmentaci a organizaci událostí v dlouhodobé paměti zkoumali Ezzyat a Davachi (2011). Metodou fMRI vyšetřovali korovou aktivitu 19 dobrovolníků, kteří četli 6 narativních textů, z nichž každý obsahoval 38 vět popisujících každodenní činnost určité postavy. Každý narativ přitom zahrnoval 8 tzv. hraničních vět (začínajících slovy „A while later..." a signalizujících začátky událostí) a 8 kontrolních vět (se slovy „A moment later...” v samotných událostech). Potvrdilo se, že epizody jsou v paměti skutečně organizovány pomocí specifického mechanismu segmentace událostí. Lze se proto domnívat, že hranice mezi událostmi narativního textu mohou ovlivňovat jejich organizaci v dlouhodobé paměti (ibid, s. 248). Autoři studie tak navázali na výzkumy, které hodnotily integrační procesy související s konstrukcí situačního modelu narativního textu, a to vyšetřováním mozkové aktivace $\mathrm{v}$ reakci na prvky narativů, které si lišily mírou konzistence a koherence (tj. integritou tematických, ev. obsahových, a kompozičních prostředků; Yarkoni, Speer, \& Zacks, 2008). 
Tabulka 1

Přehled studií mapujících aktivace mozkových oblastí/hemisfér v průběhu konstrukce situačních modelů a během segmentace vyprávění do jednotlivých akcí/událostí

\begin{tabular}{|c|c|c|c|}
\hline Autoři, rok & Metoda & $\begin{array}{l}\text { Počet a věk } \\
\text { účastníků výzkumu }\end{array}$ & Výsledky \\
\hline Speer et al. (2007) & fMRI & $\begin{array}{l}28 \text { dobrovolníků } \\
\text { (věk 19-34; } 20 \text { žen) }\end{array}$ & $\begin{array}{l}\text { První kontakt s textem byl doprovázen } \\
\text { přechodným zvýšením neuronální } \\
\text { aktivity v momentech, kdy se čtenáři } \\
\text { setkali s částmi př́běhu, které později } \\
\text { - během druhého čtení - sami označili } \\
\text { za hranice mezi dvěma událostmi. }\end{array}$ \\
\hline $\begin{array}{l}\text { Ezzyat a Davachi } \\
\text { (2011) }\end{array}$ & fMRI & $\begin{array}{l}19 \text { dobrovolníků } \\
\text { (věk 18-30; } 10 \text { žen) }\end{array}$ & $\begin{array}{l}\text { Při čtení příběhu obsahujícího časově } \\
\text { ohraničené události se ukázalo, že } \\
\text { informace, které hranicím v textu } \\
\text { předcházejí anebo po nich následují, } \\
\text { mohou být odpovědné za organizaci } \\
\text { epizod do jednotlivých segmentů } \\
\text { v epizodické paměti. }\end{array}$ \\
\hline $\begin{array}{l}\text { Yarkoni, Speer } \\
\text { a Zacks (2008) }\end{array}$ & fMRI & $\begin{array}{l}29 \text { dobrovolníků } \\
\text { (věk 18-32; } 17 \text { žen) }\end{array}$ & $\begin{array}{l}\text { Při čtení bloků nesouvisejících vět / } \\
\text { koherentních příběhů: } \\
\text { 1. nebyl nalezen přesvědčivý důkaz pro } \\
\text { lateralizaci; } \\
\text { 2. bylo zjištěno, že konstrukce } \\
\text { situačního modelu je široce } \\
\text { distribuovaným procesem; } \\
\text { 3. bylo prokázáno vyšší porozumění } \\
\text { koherentním textům než nesouvislým } \\
\text { větám, a to v důsledku konstrukce } \\
\text { situačních modelů korelujících } \\
\text { s bilaterálně zvýšenou aktivitou } \\
\text { posteriorního parietálního kortexu. }\end{array}$ \\
\hline $\begin{array}{l}\text { Martín-Loeches et } \\
\text { al. (2008) }\end{array}$ & fMRI & $\begin{array}{l}24 \text { dobrovolníků } \\
\text { (věk 19-39; } 12 \text { žen) }\end{array}$ & $\begin{array}{l}\text { Odstavce s výstižným názvem } \\
\text { zřetelně usnadňují porozumění } \\
\text { celým odstavcům. Nebylo potvrzeno, } \\
\text { že by PH měla důležitější úlohu } \\
\text { v recepci „nenazvaných“ textů než LH. } \\
\text { Nejvýrazněji se aktivoval levý angulární } \\
\text { gyrus (BA 39) - závit nazývaný } \\
\text { jako „Geschwindovo teritorium“ } \\
\text { a považovaný za „třetí jazykovou oblast“ } \\
\text { vedle oblasti Brocovy a Wernickeovy. }\end{array}$ \\
\hline
\end{tabular}

Pozn.: BA - Brodmannova area, mapa mozkové kůry vytvořená německým anatomem Korbinianem Brodmannem, publikovaná v roce 1909, dodnes v neuroanatomických popisech široce přijímaná a využívaná. 
Studie, které v uplynulých pěti letech mapovaly korovou aktivaci v průběhu porozumění narativu, upozornily na význam distribuované sítě kortikálních oblastí, mezi nimiž hraje důležitou roli přední část temporálního laloku (ATL; viz Ferstl et al., 2008) a dorsomediálního prefrontálního kortexu (DMPFC; viz Friese et al., 2008). Yarkoni, Speer a Zacks (2008) ovšem zdůraznili, že i navzdory nalezeným shodám ve vymezování korových oblastí stále přetrvává otázka, zda specifikum porozumění narativnímu textu nelze účinněji pozorovat a popsat na základě rozdílů v aktivaci hemisfér než na úrovni činnosti konkrétních mozkových oblastí. V této souvislosti autoři studie zmínili výsledky výzkumů, které prokázaly, že pro konstrukci situačních modelů narativního textu má specifickou roli pravá hemisféra (PH) a že její úloha je na úrovni porozumění textu ještě významnější než během porozumění jednotlivým větám (Robertson et al., 2000). Autoři se pokusili tento předpoklad ověřit. S využitím fMRI vyšetřovali 29 praváků, kteří četli bud' stručné příběhy záměrně konstruované jako koherentní, anebo soubory vět sestavených z vybraných narativů tak, aby koherentní př́běh netvořily. Čtení předložených pasáží (celkem 56 scén z knihy o denní činnosti sedmiletého chlapce, rozdělených na 28 bloků souvislých a 28 bloků nesouvislých textů) bylo následováno pamětovým testem, $v$ němž účastníci výzkumu měli za úkol (1) vybrat z nabídky čtyř položek jednu větu, která se objevila v předchozím textu, (2) a výběrem ze čtyř možností odpovědět na dvě otázky vztahující se ke každé z 28 přečtených textových celků. Studie identifikovala distribuovanou sít frontálních, temporálních a parietálních regionů spojených s porozuměním narativu. Nepodala však žádné důkazy pro tvrzení, že porozumění narativním textům závisí na $\mathrm{PH}$ ve větší míře než porozumění samostatným větám. Nenašel se ani žádný přesvědčivý důkaz pro lateralizaci: oblasti v obou hemisférách přechodně zvyšovaly aktivaci v průběhu času (bilaterálně i v dorsomediálním prefrontálním kortexu), což se shoduje s nálezy přehledové studie Ferstlové (2007), která identifikovala široce bilaterální aktivace spojené s kontrasty mezi koherentním a nekoherentním textem.

Možnou příčinu nesrovnalostí v pojetí role PH během porozumění textu a při konstruování kauzálních inferencí se pokusili vysvětlit Prat, Mason a Just (2011). Metodou fMRI vyšetřovali korovou aktivaci 18 dobrovolníků (věk 19-25; 12 žen) s větší a menší čtenářskou zkušeností. Sledovaní jedinci četli 46 textových pasáží, z nichž každá obsahovala 2 věty a lišila se mírou kauzální souvislosti nebo prrítomností/absencí spojovacích výrazů. Výsledky ukázaly, že role PH se liší v závislosti na specifických funkčních charakteristikách. 
U méně zkušených čtenářủ byla prokázána významně vyššíaktivita v oblastech PH (homologických s jazykovými oblastmi LH) než u čtenářu zkušenějších. Rozdíl mezi oběma skupinami čtenářủ se projevil zejména při vnímání a zpracovávání recepčně náročných pasáží (tj. koherentních/nekohezních a méně koherentních/kohezních textů; ibid, s. 10). Autoři studie vyslovili názor, že právě modifikace textové charakteristiky a rozdílná čtenářská úroveň testovaných jedinců mohou být hlavní prríčinou nesrovnalostí ve výsledcích výzkumů oblastí $\mathrm{PH}$, které se podílejí na inferenčních procesech v porozumění narativnímu textu.

Dalším tématem výzkumných studií, které jsme do přehledu zařadili, byly konstrukce inferencí (tj. reprezentací informací, které nejsou explicitně uvedeny v textu, ale mohou být odvozeny na základě předchozích znalostí; celkem 5 nalezených studií). Pozitronovou emisnítomografii (PET) využili Kim et al. (2012) k sledování kontrastů, které charakterizují neuronální koreláty inferenčních procesů v průběhu vnímání a zpracovávání různě koherentních textů. Deseti dobrovolníkům (8 žen; prům. věk 22 ) byly prezentovány dvě verze dvaceti př́iběhů v délce tří vět (lišících se mírou koherence). První dvě věty byly $\mathrm{v}$ obou typech př́iběhů identické, kauzální souvislost mezi druhou a třetí větou se lišila $\mathrm{v}$ závislosti na experimentálních podmínkách: u silně koherentních příběhů byla třetí věta konstruována tak, aby ji bylo možno porozumět bez nutnosti generovat inference; u slabě koherentních příběhů byla poslední věta obtížně předvídatelná a k vytvoření koherentního příběhu vyžadovala generaci inferencí. Zatímco slabě koherentní příběhy vyvolaly aktivaci levého středního temporálního gyru, silně koherentní texty aktivovaly dorsomediální prefrontální kortex, přední cingulární kortex a precuneus, tedy oblasti, které aktivují i pocity obeznámenosti a vybavování vzpomínek z autobiografické paměti. Autoři studie usoudili, že silně koherentní příběhy mohou při čtení narativních textů vyvolat i relevantní schéma nebo scénář př́iběhu, známé epizody nebo obecné představy o světě.

Bylo zjištěno, že dorsomediální prefrontální kortex aktivují i úlohy zatěžující mentalizaci (orig. theory of mind, zkratka ToM, doslovně „teorie duševních stavů“). Mentalizaci vysvětluje Koukolík (2010, s. 10) jako (1) „schopnost chápat, že pozorované osoby nebo věci, které nějakým způsobem jednají, nebo mají tuto schopnost (orig. agents), jsou nositelé duševních stavů, které nelze pozorovat přímo, například přesvědčení, víry, touhy po něčem," a jako (2) „schopnost vysvětlit a správně nebo mylně předpovídat chování »agen- 
tů« v pojmech těchto duševních stavů“. Mason a Just (2011) se domnívají, že zapojení kortikálních sítí aktivovaných úlohami zatěžujícími mentalizaci lze očekávat i v průběhu čtení narativních textů. Př́iběhy, v nichž se vyskytují různé postavy, totiž vypovídají i o mentálních stavech, které rozvíjejí klíčové motivické celky a tematiku narativů. Schopnost porozumět cílům a záměrům postav se pak jeví jako rozhodující i pro čtenářské porozumění narativním textům. Autoři studie pomocí fMRI vyšetřovali 16 univerzitních studentů (6 mužů, 10 žen), kteř́i četli 30 příběhů $v$ délce tří vět. $V$ pořadí druhá věta byla vždy formulována tak, aby umožňovala generovat predikativní inferenci, založenou bud' na záměru postavy (lidské intencionalitě), anebo na řetězci kauzálně souvisejících (snadno vizualizovaných) akcí/událostí. Studie potvrdila hypotézu, že mozkové oblasti se při zpracovávání diskurzu aktivují $\mathrm{v}$ závislosti na tom, jakou povahu má inference. $\mathrm{V}$ souladu $\mathrm{s}$ ToM byla při čtení pasáží založených na záměru postavy potvrzena vyšší aktivace v pravé temporoparietální junkci než při čtení kauzálních akcí/událostí. V průběhu čtení pasáží obou typů pak byla zjištěna činnost oblastí, které aktivují i úlohy zatěžující mentalizaci (mediální a superiorní frontální oblasti, inferiorní gyrus frontalis bilaterálně, posteriorní část levého superiorního temporálního gyru, anteriorní temporální gyrus bilaterálně).

Přehled dalších studií, které mapovaly neuronální koreláty inferencí v průběhu čtení narativních textů, poskytuje tabulka 2 .

Ostatní témata, jimiž se autoři zabývali v oblasti sledování korové aktivace $\mathrm{v}$ průběhu čtení a porozumění narativu/diskurzu, tvořila: problematika emocionálních/kognitivních procesů při čtení narativů (Benelli et al., 2012), mapování korové aktivity u dětských čtenářů (Berl et al., 2010), během porozumění konotacím a nepřímým obrazným pojmenováním/metaforám (Mashal et al., 2009; Mashal \& Faust, 2010) a v reakci na texty zahrnující cílové směřování lidské aktivity, pohyb a manipulaci s předměty (Speer et al., 2009; Deen \& McCarthy, 2010). 
Tabulka 2

Přehled dalších studií zjištujujicích neuronální koreláty inferenčních procesů při čtení narativních textů

\begin{tabular}{|c|c|c|c|}
\hline Autoři, rok & Metoda & $\begin{array}{l}\text { Počet a věk účastníků } \\
\text { výzkumu }\end{array}$ & Výsledky \\
\hline Friese et al. (2008) & fMRI & $\begin{array}{l}13 \text { dobrovolníků } \\
\text { (7 žen; prům. věk 22,8) }\end{array}$ & $\begin{array}{l}\text { V průběhu generování inferencí se } \\
\text { významně aktivoval dorsomediální } \\
\text { prefrontální kortex (jehož aktivita } \\
\text { byla potvrzena i v předchozích } \\
\text { výzkumech mentalizace, uvažování } \\
\text { a autobiografické či epizodické } \\
\text { paměti). }\end{array}$ \\
\hline $\begin{array}{l}\text { Baretta et al. } \\
\text { (2012) }\end{array}$ & EEG & $\begin{array}{l}12 \text { univerzitních } \\
\text { studentů, mužů } \\
\text { (prům. věk 22) }\end{array}$ & $\begin{array}{l}30 \text { narativních a } 30 \text { výkladových } \\
\text { pasáží (v délce čtyř vět) se } \\
\text { lišilo závěrečnou výpovědí: } \\
\text { 1. první tři věty vedly k závěru } \\
\text { uvedenému ve čtvrté větě; } \\
\text { 2. anebo poslední věta přinesla } \\
\text { překvapivý závěr. } \\
\text { Ukázalo se, že typ textu ovlivňuje } \\
\text { zatížení v různých mozkových } \\
\text { hemisférách (PH se výrazněji } \\
\text { aktivovala vždy při čtení čtvrté věty, } \\
\text { LH při čtení funkčních slov ve třetí } \\
\text { větě). }\end{array}$ \\
\hline Chow et al. (2008) & fMRI & $\begin{array}{l}15 \text { univerzitních } \\
\text { studentů (11 žen; prům. } \\
\text { věk } 24)\end{array}$ & $\begin{array}{l}\text { Při generování inferencí zjištěna } \\
\text { aktivace v různých korových } \\
\text { oblastech mozku (zejm. v levém } \\
\text { anteriorním prefrontálním kortexu } \\
\text { a v levém gyru frontalis inferior, } \\
\text { tj. v oblastech, které jsou důležité } \\
\text { v strategických inferencích } \\
\text { a v hodnocení koherencí). }\end{array}$ \\
\hline
\end{tabular}

Většina studií zařazených do tohoto přehledu sledovala korovou aktivaci bez ohledu na specifika dětských čtenářủ. Cenné výsledky proto přinesla analýza efektů jazykové úlohy, věku a neuropsychologických dovedností, kterou provedli Berl et al. (2010). Pomocí fMRI vyšetřovali proměny aktivity mozku 74 dětí (v rozmezí věku 4-12 let; 43 dívek), které četly a poslouchaly zadané prŕběhy. Děti aktivovaly stejné základní kortikální oblasti jako dospělí, zkoumaná neuronální činnost však byla podmíněna povahou úlohy (čtení/poslech) a lišila se i v závislosti na sledovaných věkových kohortách. (1) Čtení aktivovalo větší počet korových oblastí než poslech. Autoři studie 
tak zohlednili skutečnost, že čtení vyvolává výraznější kognitivní zatížení než poslech - čtenář musí vyvinout jisté úsilí a proměnit informace a významy v konkrétní a jedinečné představy. Rozdíly mezi čtením a poslechem se projevily především v začlenění temporo-okcipitálních oblastí zahrnujících i gyrus fusiformis, který se aktivuje mj. v průběhu zpracovávání slov a jehož hypoaktivita je podle dosavadních výzkumů sensitivním markerem dyslexie. Začlenění těchto oblastí se liší podle frekvence a délky slov, v závislosti na ortografické složitosti a morfologii. (2) Děti ve věku od šesti let aktivovaly frontální oblasti častěji než děti mezi čtvrtým a šestým rokem. Aktivace frontálních oblastí přitom pozitivně korelovala s lepším výkonem v odpovědích na otázky vztahující se k poslechu př́běhu. Lze proto usuzovat, že aktivace frontálních neuronových sítí, která se projevila u dětí od šesti let, koreluje s lepším výkonem verbálního dekódování jazykového materiálu a lepším porozuměním narativu než u dětí mezi čtvrtým a šestým rokem.

Zajímavé výsledky poskytl výzkum, který realizovali Speer et al. (2009; výsledky zmiňuje i Koukolík, 2012, s. 193). Bylo vybráno 28 dobrovolníků (věk 19-34; 20 žen), kteří četli čtyři jednoduchá vyprávění o denní činnosti sedmiletého chlapce (o ranním vstávání, snídani, o vyučovacích hodinách ve škole atd.). Pomocí fMRI se vědci pokusili zjistit, jaké mozkové oblasti jsou při čtení př́iběhu aktivovány. Výzkum dospěl k několika závěrům. (1) Čtenáři si v mozku aktivují specifické vizuální, motorické a konceptuální funkce reálných činností, zatímco čtou o podobných aktivitách v textu (Speer et al., 2009, s. 995). (2) Mozkové oblasti začleněné v procesech cílového směřování lidské aktivity, pohybu a manipulace $\mathrm{s}$ předměty $\mathrm{v}$ reálném světě zvýšily svou aktivitu $\mathrm{v}$ momentech, kdy se $\mathrm{s}$ nimi čtenáři setkali $\mathrm{v}$ textu vyprávění (ibid, s. 996). (3) Mozek čtenářů simuluje akce, které odpovídají osobě představitele př́běhu, cíli, prostoru i času. Aktivita mozku je totiž stejná jako v př́ípadě, že popisované akce čtenáři dělají sami (přehled viz ibid, s. 997). Autoři výzkumu navázali na výsledky studií, které již v minulosti sledovaly mozkovou aktivitu při čtení slov a frází (Pulvermüller, 2005). Tyto závěry však obohatili o zjištění, která se týkají čtení celých souvislých vyprávění.

Výsledky, k nimž dospěli Speer et al. (2009), podpořili i Deen a McCarthy (2010). Metodou fMRI vyšetřovali 15 praváků (prům. věk 22; 7 žen), kteří četli 24 krátkých př́iběhů, z nichž polovina obsahovala popisy biologického pohybu (chůze či pohyb rukou), druhá polovina nikoliv. V průběhu čtení příběhů obsahujících pohyb se silně aktivovaly tyto oblasti: bilaterálně posteriorní část sulcus temporalis superior (tj. posteriorní část rýhy mezi horním a stř̌edním spánkovým závitem - pSTS -, oblast, která reaguje i na specifické 
pohyby reálných či virtuálních/představovaných lidí), levý motorický kortex, premotorický kortex a gyrus fusiformis (podle anatomické nomenklatury gyrus occipitotemporalis superior lateralis, mající zřejmě klíčovou roli v rozpoznávání obličeje) a také oblast precuneu (kterou podle minulých studií aktivují např́klad i představy lidského pohybu). Autoři výzkumu tak dospěli k výsledkům, které korespondují se závěry behaviorálně zaměřených studií prokazujících začlenění motorického systému $\mathrm{v}$ porozumění textu (např. Taylor \& Zwaan, 2008).

Další témata, na něž se soustředily studie zařazené do tohoto přehledu, jsou analyzována $\mathrm{v}$ tabulce 3.

\subsection{Diskuse}

Studie o neuronálních korelátech čtení narativních textů, které byly zařazeny do tohoto přehledu, sledovaly několik specifických tematických oblastí. Velký význam byl v hodnocených článcích přisouzen zejména (1) výzkumu aktivace mozkových oblastí/hemisfér v průběhu konstrukce tzv. situačních modelů (ev. během segmentace vyprávění do jednotlivých akcí/událostí) a (2) vymezování kontrastů, které charakterizují neuronální koreláty inferenčních procesů. Menší pozornost byla věnována (3) výzkumu korové aktivity během porozumění konotacím a nepřímým obrazným pojmenováním (metaforám), dále pak otázkám role emocionálních/kognitivních procesů při čtení narativů, činnosti mozkových oblastí u dětských čtenářủ a sledování aktivace motorického kortexu nebo oblastí, které reagují na specifické pohyby reálných či virtuálních/představovaných lidí.

Práce zařazené do našeho přehledu jen ojediněle zohledňovaly specifika pubescentních a prepubescentních čtenářù, výsledky jednotlivých experimentů tak zpravidla mají obecnou platnost a nelze z nich vyvozovat závěry explicitně platné pro dětskou recepci. Jak je patrné z uvedených přehledů, k objasnění mechanismů procesu čtení narativního textu jsou nejčastěji dostupné studie, které byly realizovány na vzorku adolescentních a dospělých čtenářu. Experimentální ověření jejich platnosti pro pubescentní a prepubescentní čtenářství pak může být výzvou novým výzkumům tohoto typu. Korovou aktivitu dětských čtenářù specifikovala pouze jediná studie zařazená do našeho přehledu (Berl et al., 2010). Prokázala, že děti ve věku 4-12 let aktivovaly stejné základní kortikální oblasti jako dospělí čtenáři. Sledovaná korová aktivita se lišila výhradně v závislosti na individuálních věkových rozdílech a typu konkrétních jazykových úloh. 
Tabulka 3

Přehled studií zabývajících se ostatními zkoumanými tématy

\begin{tabular}{|c|c|c|c|}
\hline Autoři, rok & Metoda & $\begin{array}{l}\text { Počet a věk } \\
\text { účastníků výzkumu }\end{array}$ & Výsledky \\
\hline $\begin{array}{l}\text { Benelli et al. } \\
\text { (2012) }\end{array}$ & fMRI & $\begin{array}{l}18 \text { účastníků } \\
\text { (věk 18-45; } 12 \text { žen) }\end{array}$ & $\begin{array}{l}\text { Při čtení čtyř verzí emocionálně } \\
\text { abstraktních popisů afektivně } \\
\text { evokovaných scén byla zjištěna výrazná } \\
\text { aktivace v korových oblastech, které jsou } \\
\text { spojeny se sémantickým vyhledáváním } \\
\text { a zpracováváním pamětových úloh } \\
\text { (přední insula/ventrolaterální } \\
\text { prefrontální kortex) a jejichž aktivita byla } \\
\text { prokázána i při čtení emočně nabuzujících } \\
\text { narativů a vět s afektivně sémantickým } \\
\text { obsahem/afektivní prozodií (mediální } \\
\text { oblasti frontálního kortexu zasahujícího } \\
\text { i ACC). }\end{array}$ \\
\hline $\begin{array}{l}\text { Mashal et al. } \\
\text { (2009) }\end{array}$ & fMRI & $\begin{array}{l}15 \text { účastníků } \\
\text { (věk 22-28; } 6 \text { žen) }\end{array}$ & $\begin{array}{l}\text { Při čtení vět obsahujících metaforické } \\
\text { fráze z hebrejské umělecké literatury } \\
\text { byla zjištěna vyšší aktivace v oblastech } \\
\text { LH než v oblastech PH a dále pak v levém } \\
\text { dorsolaterálním prefrontálním kortexu, } \\
\text { což může reflektovat větší zatížení } \\
\text { systémů epizodické a sémantické paměti. }\end{array}$ \\
\hline $\begin{array}{l}\text { Mashal a Faust } \\
\text { (2010) }\end{array}$ & fMRI & $\begin{array}{l}15 \text { účastníků (věk } \\
22-28 ; 6 \text { žen) }\end{array}$ & $\begin{array}{l}\text { Při čtení nemetaforických textů byla } \\
\text { prokázána bilaterálně vyšší aktivace } \\
\text { v anteriorní části superiorního } \\
\text { temporálního gyru než při čtení } \\
\text { metaforických textů převzatých } \\
\text { z hebrejské umělecké literatury. To bylo } \\
\text { pravděpodobně vyvoláno vyšší zátěží } \\
\text { vyplývající z nesouladu mezi formou } \\
\text { a typem textu (každý metaforický text } \\
\text { byl původně prozaický, autoři výzkumu } \\
\text { jej však rozčlenili na čtyři nerýmované } \\
\text { verše, zatímco text nemetaforický } \\
\text { zůstal v prozaické podobě). Lze se tedy } \\
\text { domnívat, že vnímání a zpracovávání } \\
\text { textu mohou podmiňovat vztahy mezi } \\
\text { typem textu (metaforické a nemetaforické } \\
\text { povahy) a jeho formou (prozaickou, } \\
\text { veršovou). }\end{array}$ \\
\hline
\end{tabular}

Pozn.: ACC - anteriorní cingulární kortex; pSTS - posteriorní část rýhy mezi horním a středním spánkovým závitem. 
V dohledaných studiích byly podány důkazy o tom, že činnost korových oblastí mozku se mění v průběhu vnímání a zpracovávání různě koherentních textů. Ukázalo se, že silně koherentní př́iběhy mohou při čtení narativních textů vyvolat ve vědomí čtenáře relevantní schéma nebo scénář př́iběhu (Kim et al., 2012). Aktivace mozkových oblastí se ovšem může lišit i v závislosti na tom, zda je inference založena na záměru postavy (lidské intencionalitě), anebo na řetězci kauzálně souvisejících (snadno vizualizovaných) událostí. V průběhu čtení těchto pasáží byla prokázána činnost oblastí, které aktivují i úlohy zatěžující mentalizaci (Mason \& Just, 2011). Příběhy, v nichž se vyskytují různé postavy, totiž vypovídají o mentálních stavech, které rozvíjejí klíčové motivické celky a tematiku narativů. Schopnost porozumět cílům a záměrům jednotlivých postav vystupujících v příběhu se pak jeví jako rozhodující i pro čtenářské porozumění narativním textům.

Ukázalo se, že změny, které se vztahují k cílům postav vystupujících v příběhu, korelují také s mechanismem, jímž si čtenáři rozčleňují příběh do dílčích událostí (Speer et al., 2007). Procesy, které vedou ke konstrukci situačních modelů narativu/diskurzu, tak mohou objasňovat i studie, které dokazují, že jednotlivé epizody jsou $\mathrm{v}$ paměti organizovány pomocí specifického mechanismu segmentace událostí (Ezzyat \& Davachi, 2011). S využitím funkčních zobrazovacích metod bylo zjištěno, že porozumění textu je zprostředkováno zejména třemi mozkovými oblastmi: přední částí temporálního laloku (oblastí, jejíž význam byl prokázán v prủběhu generování a interpretace sémantického kontextu příběhu), temporoparietální junkcí (v porozumění kauzalitě a intencionalitě příběhu) a dorsomediálním prefrontálním kortexem (např́íklad při zpracovávání koherentních příběhů a v úlohách zatěžujících mentalizaci; viz Kim et al., 2012). Existují však důkazy také o tom, že čtenáři si v mozku aktivují specifické vizuální, motorické a konceptuální funkce reálných činností, zatímco čtou o podobných aktivitách v textu (Speer et al., 2009). Výzkum, který realizovali Deen a McCarthy (2010), ukázal, že v průběhu čtení př́iběhů obsahujících pohyb se mohou silně aktivovat oblasti, které reagují i na specifické pohyby reálných či virtuálních/představovaných lidí. Tato zjištění přitom korelují i s dalším empirickým ověřováním zapojení motorického systému v průběhu porozumění textu (Taylor \& Zwaan, 2008).

Důležitou úlohu mohou v charakteristice mechanismů čtenářských zážitků sehrát také studie, které na základě poznatků o korové aktivaci mozkových oblastí dokládají přirozenou součinnost/neoddělitelnost kognitivní a emotivní složky v průběhu čtení narativních textů. Do přehledu jsme zařadili 
i práci, která zjistila, že při čtení čtyř verzí emocionálně abstraktních popisů afektivně evokovaných scén se mohou výrazně aktivovat korové oblasti spojené se sémantickým vyhledáváním a zpracováváním pamětových úloh (Benelli et al., 2012). Jde o poznatky, které přispívají k objasnění vzniku čtenářského zážitku z hlediska vztahu kognitivních a emocionálních aktivit, a to s pomocí důkazů o aktivitě přední insuly a ventrolaterálního prefrontálního kortexu.

Poznatky, k nimž dospěly výzkumné práce zařazené do našeho přehledu, lze konfrontovat se závěry přehledové studie o významu neurověd pro dětské čtenářství a jazykové/literární vzdělávání (Hruby \& Goswami, 2011). Její autoři konstatují, že neurovědy mají hluboký potenciál rozšířit naše porozumění čtenářským mechanismům, jejich vývoji a funkcím. Pokud porozumíme neurofyziologickým procesům, které korelují s čtením a jeho výukou, Hruby a Goswamiová (2011, s. 169) se domnívají, že neurovědy začnou pravděpodobně brzy ovlivňovat naše teoretické konstrukty o čtenářském vzdělávání, a tím mohou začít spolurozhodovat o cílech a směřování vzdělávací politiky. Na základě výsledků, k nimž jsme dospěli v prezentované přehledové studii, máme za to, že využití neuropsychologických a neurolingvistických poznatků v teoretické i aplikační rovině věd o výchově a vzdělávání bude v příštích letech skutečně patřit mezi velké výzvy jak pro obecnou didaktiku, tak pro didaktiky oborové. Na druhé straně, i k nadějným a slibným výsledkům zobrazovacích studií nelze přistupovat bez náležité kritické reflexe.

1. Nelze zapomínat, že z neurovědních poznatků není možné vyvozovat konkrétní didaktické závěry bez patřičných klinických experimentů, které by ověřily praktických přínos a efektivitu možných neurodidaktických východisek. Výsledky výzkumů mapujících korovou aktivaci mozku proto nelze $\mathrm{v}$ žádném případě prostě aplikovat na konkrétní výchovně-vzdělávací činnost.

2. Je třeba mít na paměti, že výzkum korové aktivity v průběhu čtení narativních textů je často realizován na vzorku adolescentních či dospělých jedinců. Platnost výsledků pak není možné vztahovat i na mechanismy dětského čtenářství, aniž by se poukázalo na rozdíly, které mohou v různých testovaných skupinách vzniknout.

3. Rozdíly ve výzkumných výsledcích se mohou projevit i v závislosti na rozličných experimentálních podmínkách a využití různých zobrazovacích metod. To se v našem přehledu ukázalo například v nesrovnalostech 
pojetí role PH během porozumění textu a při konstruování kauzálních inferencí.

4. V konstrukci adekvátních závěrů nelze opomíjet ani názory, které se $\mathrm{k}$ aplikaci neurovědních poznatků ve výuce stavějí kriticky. Autoři těchto studií zpravidla upozorňují na problém triviálních a nenáležitých interpretací výsledků jednotlivých neurovědních experimentů. Jak ukazují Vul et al. (2009), k nadhodnocování poznatků o korové aktivitě během porozumění textu často vede nedostatečné rozlišování neuronálních korelátů čtení a kauzálního vztahu mezi neuronální a čtenářskou aktivitou. To by mělo pedagogy varovat před urychleným přejímáním neurobiologických poznatků do praxe, jakož i před vědecky neověřenou aplikací těchto zjištění v konkrétních vzdělávacích programech a strategiích, případně v metodice a teorii dětského čtenářství.

\section{Závěr}

V příspěvku byly nastíněny základní aspekty současného dětského čtenářství a didaktické transformace obsahu v literární výchově, jakož i poznatky o dovednostech žákovské komunikace $s$ uměleckými texty a možnostech současného vědeckého přístupu $\mathrm{k}$ recepci uměleckého textu. Představeny byly studie, které poukázaly, že čtenářské a pedagogické výzkumy mohou čerpat poznatky mimo jiné i z disciplín přistupujících $\mathrm{k}$ procesům lidského učení a k popisu čtenářské aktivity s pomocí výzkumů orgánové, buněčné i molekulární úrovně mozkové činnosti.

Cílem tohoto příspěvku bylo vyhledat výzkumné práce, které funkčními či elektrofyziologickými metodami vyšetřovaly aktivaci korových oblastí mozku v průběhu čtení příběhu/vyprávění (tj. narativu či diskurzu), a s pomocí přehledových studií podat systematický souhrn výsledků, k nimž vybrané výzkumy dospěly. Ukázalo se, že dohledané práce jen ojediněle zohledňovaly specifika pubescentních a prepubescentních čtenářů, i přesto však podaly široký přehled možností, jimiž lze objasňovat mechanismy procesu čtení narativního textu na úrovni korové aktivace mozku. Velký význam byl v hodnocených článcích přisouzen zejména výzkumu činnosti mozkových oblastí/hemisfér v průběhu konstrukce tzv. situačních modelů (ev. během segmentace vyprávění do jednotlivých akcí/událostí) a vymezování kontrastů, které charakterizují neuronální koreláty inferenčních procesů. 
Přehledové studie o neuronálních korelátech čtení vycházejí z předpokladu, že neurovědy budou pravděpodobně brzy ovlivňovat naše teoretické konstrukty o čtenářském vzdělávání, a tím mohou začít spolurozhodovat o cílech a směřování vzdělávací politiky. Na základě výsledků, k nimž jsme dospěli v prezentované přehledové studii, se domníváme, že poznatky o korové aktivitě mozku jsou zcela jistě perspektivní jak pro teoretickou, tak pro aplikační rovinu věd o výchově a vzdělávání. Jak ale naznačují některé kritické stati, k možnostem didaktické aplikace výsledků zobrazovacích studií nelze přistupovat bez náležitého experimentálního ověření, teoretického zhodnocení a kritické reflexe.

\section{Literatura}

Baretta, L., Tomitch, L. M. B., Lim, V. K., \& Waldie, K. E. (2012). Investigating reading comprehension through EEG. Ilha do Desterro, 63, 69-99.

Berl, M. M., Duke, E. S., Mayo, J., Rosenberger, L. R., Moore, E. N., VanMeter, J., ... Gaillard, W. D. (2010). Functional anatomy of listening and reading comprehension during development. Brain and Language, 114(2), 115-125.

Benelli, E., Mergenthaler, E., Walter, S., Messina, I., Sambin, M., Buchheim, A., ... Viviani, R. (2012). Emotional and cognitive processing of narratives and individual appraisal styles: Recruitment of cognitive control networks vs. modulation of deactivations. Frontiers in Human Neuroscience, 6(AUGUST), 1-16.

Chow, H. M., Kaup, B., Raabe, M., \& Greenlee, M. W. (2008). Evidence of fronto-temporal interactions for strategic inference processes during language comprehension. NeuroImage, 40(2), 940-954.

Deen, B., \& McCarthy, G. (2010). Reading about the actions of others: Biological motion imagery and action congruency influence brain activity. Neuropsychologia, 48(6), 1607-1615.

Emmott, C. (1997). Narrative comprehension. Oxford: Oxford University Press.

Ezzyat, Y., \& Davachi, L. (2011). What constitutes an episode in episodic memory? Psychological Science, 22(2), 243-252.

Ferstl, E. C. (2007). The functional neuroanatomy of text comprehension: what's the story so far? In F. Schmalhofer \& C. A. Perfetti (Eds.), Higher level language processes in the brain: Inference and comprehension processes (s. 53-102). Mahwah, NJ: Lawrence Erlbaum.

Ferstl, E. C., Neumann, J., Bogler, C., \& Von Cramon, D. Y. (2008). The extended language network: A meta-analysis of neuroimaging studies on text comprehension. Human Brain Mapping, 29(5), 581-593.

Friedrich, G. (2005). Allgemeine Didaktik und Neurodidaktik. Frankfurt am Main: Peter Lang.

Friese, U., Rutschmann, R., Raabe, M., \& Schmalhofer, F. (2008). Neural indicators of inference processes in text comprehension: An event-related functional magnetic resonance imaging study. Journal of Cognitive Neuroscience, 20(11), 2110-2124.

Gabal, I., \& Václavíková-Helšusová, L. (2005). Jak čtou české děti? Analýza výsledků sociologického výzkumu. Knihovnický zpravodaj Vysočina, 5(2). Dostupné z http://kzv.kkvysociny.cz/ archiv.aspx?id=171\&idr=1\&idci=1 
Gerrig, R. (1998). Experiencing narrative worlds. New Haven: Westview Press.

Herrmann, U. (2006). Neurodidaktik - Grundlagen und Vorschläge für gehirngerechtes Lehren und Lernen. Weinheim und Basel: Beltz Verlag.

Hluštík, P., Horák, D., Herzig, R., \& Kaňovský, P. (2008). Funkční zobrazování mozku pomocí magnetické rezonance v neurologii. Neurologie pro praxi, 9(2), 83-86.

Hník, O. (2007). Hravá interpretace v hodinách čtení a literární výchovy. Praha: Nakl. H+H.

Houdek, P. (2008). Časové preference z pohledu kognitivní neurovědy. E-Logos. Electronic Journal for Philosophy. Dostupné z http://nb.vse.cz/kfil/elogos/mind/houdek08.pdf

Hruby, G. G., \& Goswami, U. (2011). Review of research: Neuroscience and reading. A review for reading education researchers. Reading Research Quarterly, 46(2), 156-172.

Chlebus, P., Mikl M., Brázdil M., \& Krupa P. (2005). Funkční magnetická rezonance - úvod do problematiky. Neurologie pro praxi, 6(3), 133-139.

Janík, T. (2009). Oborové a předmětové didaktiky. In J. Průcha (Ed.), Pedagogická encyklopedie (s. 656-660). Praha: Portál.

Janík, T., \& Slavík, J. (2009). Obsah, subjekt a intersubjektivita v oborových didaktikách. Pedagogika, 59(2), 116-135.

Janko, T. (2012). Reprezentace obsahu: psychologická východiska a didaktické souvislosti. Pedagogická orientace, 22(1), 23-40.

Jedličková, A. (2010). Zkušenost prostoru. Vyprávění a vizuální paralely. Praha: Academia.

Jonák, Z. (2007). Úloha emocí při recepci literárního díla. Dostupné z http://clanky.rvp.cz/ clanek/k/z/1131/uloha-emoci-pri-recepci-literarniho-dila.html

Kim, S., Yoon, M., Kim, W., Lee, S., \& Kang, E. (2012). Neural correlates of bridging inferences and coherence processing. Journal of Psycholinguistic Research, 41(4), 311-321.

Knecht, P. (2007). Didaktická transformace aneb od „didaktického zjednodušení" k „didaktické rekonstrukci“. Orbis scholae, 1(1), 67-81.

Koten, J. (2012). Prostorová reference v teorii vyprávění. In P. Komenda, L. Malinová, \& R. Změlík (Eds.), Místo - prostor - krajina v literatuře a kultuře. Olomouc: UP.

Koukolík, F. (2010). Lidství. Neuronální koreláty. Praha: Galén.

Koukolík, F. (2012). Lidský mozek. Funkční systémy. Norma a poruchy. Praha: Galén.

Koštálová, H., Šafránková, K., Hausenblas, O., \& Šlapal, M. (2010). Čtenářská gramotnost jako vzdělávací cíl pro každého žáka. Praha: Česká školní inspekce.

Kulišták, P. (2011). Neuropsychologie. Praha: Portál.

Kusá, J. (2012). Pedagogická reflexe multikulturní výchovy při práci s literárními texty na 2. stupni základních škol (Disertační práce). Olomouc: UP.

Lederbuchová, L. (2004). Dítě a kniha: o čtenářství jedenáctiletých. Plzeň: Nakl. Aleš Čeněk.

Lederbuchová, L. (2006). Literárněteoretické poznatky v literární výchově. Dostupné z http:// clanky.rvp.cz/clanek/c/ZVA/444/literarneteoreticke-poznatky-v-literarni-vychove.html/

Marmolejo-Ramos, F., de Juan, M. R. E., Gygax, P., Madden, C. J., \& Roa, S. M. (2009). Reading between the lines: The activation of background knowledge during text comprehension. Pragmatics and Cognition, 17(1), 77-107.

Martín-Loeches, M., Casado, P., Hernández-Tamames, J. A., \& Álvarez-Linera, J. (2008). Brain activation in discourse comprehension: A 3t fMRI study. NeuroImage, 41(2), 614-622.

Mason, R. A., \& Just, M. A. (2011). Differentiable cortical networks for inferences concerning people's intentions versus physical causality. Human Brain Mapping, 32(2), 313-329. 
Mashal, N., Faust, M., Hendler, T., \& Jung-Beeman, M. (2009). An fMRI study of processing novel metaphoric sentences. Laterality, 14(1), 30-54.

Mashal, N. \& Faust, M. (2010). The effects of metaphoricity and presentation style on brain activation during text comprehension. Metaphor and Symbol, 25(1), 19-33.

Palečková, J., Tomášek, V., \& Basl, J. (2010). Hlavní zjištění výzkumu PISA 2009. Umíme ještě číst? Praha: Ústav pro informace ve vzdělávání.

Pourová, J. (1996). Výzkum současného stavu četby a příjmu literárních děl 14-18letými čtenáři se zaměřením na estetickou funkci. Čtenář, 48(7-8), 256-262.

Prat, C. S., Mason, R. A., \& Just, M. A. (2011). Individual differences in the neural basis of causal inferencing. Brain and Language, 116(1), 1-13.

Preis, G. (1998). Neurodidaktik. Theoretische und praktische Beiträge. Herbolzheim: Centaurus Verlag.

Preiss, M., \& Kučerová, H. et al. (2006). Neuropsychologie v psychiatrii. Praha: Grada.

Pulvermüller, F. (2005). Brain mechanisms linking language and action. Nature Reviews Neuroscience, 6(7), 576-582.

Rámcový vzdělávací program pro základní vzdělávání. (2007). Praha: VÚP.

Robertson, D. A., Gernsbacher, M. A., Guidotti, S. J., Robertson, R. R. W., Irwin, W., Mock, B. J., \& Campana, M. E. (2000). Functional neuroanatomy of the cognitive process of mapping during discourse comprehension. Psychological Science, 11(3), 255-260.

Ryan, M.-L. (2001). Narrative as virtual reality. Baltimore: John Hopkins University Press.

Schmiedtová, B., \& Flanderková, E. (2012). Neurolingvistika: předmět, historie, metody. Slovo a slovesnost, 73(1), 46-62.

Sedláková, M. (2004). Vybrané kapitoly z kognitivní psychologie. Praha: Grada.

Slavík, J. (2001). Umění zážitku, zážitek umění. Teorie a praxe artefiletiky I. Praha: Univerzita Karlova v Praze - Pedagogická fakulta.

Slavík, J. (2011). K předmětu didaktik v estetických oborech vzdělávání. Pedagogická orientace, 21(2), 207-225.

Speer, N. K., Zacks, J. M., \& Reynolds, J. R. (2007). Human brain activity time-locked to narrative event boundaries: Research article. Psychological Science, 18(5), 449-455.

Speer, N. K., Reynolds, J. R., Swallow, K. M., \& Zacks, J. M. (2009). Reading stories activates neural representations of visual and motor experiences. Psychological Science, 20(8), 989-999.

Šafránková, K. (2012). Jak vizualizace napomáhá čtení. Kritické listy, (48), 4-8.

Šlapal, M. (2010). Dílna čtení v praxi. In H. Koštálová, et al., Čtenářrsá gramotnost jako vzdělávací cíl pro každého žáka (s. 28-42). Praha: Česká školní inspekce.

Taylor, L. J., \& Zwaan, R. A. (2008). Motor resonance and linguistic focus. Quarterly Journal of Experimental Psychology, 61(6), 896-904.

Toman, J. (1999). Aktuální profil dětského čtenáře. In Slovo a obraz v komunikaci s dětmi (s. 6-14). Ostrava: Pedagogická fakulta OU.

Toman, J. (2004). Současný prepubescentní čtenář a jeho proměny. Knihovnický zpravodaj Vysočina, 4(1). Dostupné z http://kzv.kkvysociny.cz/archiv.aspx?id=404\&idr=2\&idci=6

Toman, J. (2009). Profil dětského čtenáře 21. století v badatelské reflexi (česká realita). In E. Koudelková (Ed.), Současnost literatury pro děti a mládež (s. 33-44). Liberec: Technická univerzita v Liberci.

Tuček, J. (2002). Transkraniální magnetická stimulace a její možnosti v psychiatrii. Psychiatrie pro praxi, 3(3), 121-123. 
Vala, J. (2011). Poezie v literární výchově. Olomouc: UP.

Vul, E., Harris, C., Winkielman, P., \& Pashler, H. (2009). Puzzlingly high correlations in fMRI studies of emotion, personality, and social cognition. Perspectives on Psychological Science, 4(3), 274-290.

Yarkoni, T., Speer, N. K., \& Zacks, J. M. (2008). Neural substrates of narrative comprehension and memory. NeuroImage, 41(4), 1408-1425.

Zacks, J. M., Braver, T. S., Sheridan, M. A., Donaldson, D. I., Snyder, A. Z., Ollinger, J. M. et al. (2001). Human brain activity timelocked to perceptual event boundaries. Nature Neuroscience, 4(6), 651-655.

Zwaan, R. A., Taylor, L. J., \& de Boer, M. (2010). Motor resonance as a function of narrative time: Further tests of the linguistic focus hypothesis. Brain and Language, 112(3), 143-149.

\title{
Autoři
}

PhDr. Václav Jindráček, Univerzita Jana Evangelisty Purkyně v Ústí nad Labem, Pedagogická fakulta, Katedra bohemistiky, České mládeže 8, 40096 Ústí nad Labem, jindracek@centrum.cz

doc. PaedDr. Pavel Doulík, Ph.D., Doc. PhDr. Jiř́ Škoda, Ph.D., Univerzita Jana Evangelisty Purkyně v Ústí nad Labem, Pedagogická fakulta, Katedra pedagogiky, České mládeže 8, 40096 Ústí nad Labem, pavel.doulik@ujep.cz, jiri.skoda@ujep.cz

\section{Didactic background of children's reading and perspectives of neuroscience}

\begin{abstract}
The goal of this review is to look up research studies, that have by using the functional or electrophysiological methods investigated the activation of cortical parts of brain during reading or narrating a story (narrative or discourse), and by using reviews give the overview of the results which the selected works achieved. The first part of the report is devoted to the contemporary children reading in educational contexts in literary education. In the second part an overview of research studies mapping the activation of cortical parts of the brain during the process of reading and the understanding of narrative/discourse is provided. As a source of data, the following databases were used (2007-2012): Medline, Bibliomedica, Science Direct, Web of Science, Google Scholar. 16 studies were included in the analysis. It has come to light, that the identified works considered the specifics of pubescent and prepubescent readers only in few isolated cases, yet in spite of that, gave extensive overview about the options that can be used to clarify the mechanisms of the process of reading a narrative text on the level of cortical activation of the brain. Sixteen research studies were included in the analysis. In the evaluated articles, great importance has been given to the research of activity of brain parts/hemispheres in the process of construction of the so called situational models (during the segmentation of the narrative into individual parts/events) and defining contrasts that characterize neural correlates of inferential processes.
\end{abstract}

Keywords: neuroscience, children's reading, educational content 